SECTION A

\title{
INTRODUCTION TO AND AIMS IN THE DESIGN OF EARTHQUAKE RESISTING SHEAR WALL STRUCTURES
}

\author{
R.G. Taylor*
}

\section{INTRODUCTION AND SCOPE:}

Some three years ago the New zealand National Society for Earthquake Engineering initiated a series of group discussions with the aim of examining seismic design philosophies and methodology, relevant to different types of engineering structures. The results of the first of these discussions, on the seismic design of ductile moment resisting reinforced concrete frames, were subsequently published in a series of papers in the Bulletin of the Society. The publication was followed by workshop meetings, held in the main centres of New zealand and attended mainly by practising structural engineers. During these meetings the recommendations of the group were disseminated and applied to prototype structures.

Encouraged by the success of the workshop on ductile frames a further group was formed and given instructions to review the design of reinforced concrete walls and diaphragms with the following objectives:

To provide a 'state of the art' report on Walls and Diaphragms and to provide recommendations for design practice.

2. To examine the provisions of the draft New Zealand Standard DZ 3101 Code of Practice for the Design of Concrete Structures, which was issued for comments in June 1978, and to make recommendations where improvements or modifications should be made.

3. To examine in detail the implications of the requirements of the New Zealand Standard 4203:1976, Code of Practice for General structural Design and Design Loading for buildings, with reference to earthquake resisting reinforced concrete walls, and to prepare recommendations, if necessary, for a review of the relevant provisions by the appropriate committee of the Standards Association of New Zealand.

4. To collate recommendations for publication and in preparation for a series of workshops to be held in each main centre on the subject of walls and diaphragms.

Initially, the group planned to cover a wide field including wall-frame (Mixed or Hybrid) structures and reinforced concrete masonry walls. However, in early group discussions it was found to be necessary to limit the group's discussion to cast insitu reinforced concrete shear walls because of time and financial constraints.

* Consulting Engineer, Earles and Co., Wanganui. Formerly Ministry of Works and Development.
It was hoped that with suitable modifications the recommendations presented here for reinforced concrete walls could be adapted to cover also reinforced masonry walls. The group decided not to study issues relevant to the design of reinforced masonry walls because at the same time the masonry materials code was being reviewed by a Committee of the Standards Association of New Zealand.

The consideration of hybrid structures, consisting of a combination of walls and frames, was postponed for similar reasons. Although this is recognised to be an area of considerable interest to designers, the group preferred to use the limited number of meetings to prepare exhaustive recommendations for shear wall structures only. With the detailed recommendations prepared for ductile moment resisting frames at one hand and recommendations for shear wall structures at the other, it is hoped that designers will find some guidance for the desion of structures consisting of a mixture of the two structural types specifically studied. It is hoped that the society will encourage a similar indepth study of the seismic design of combined frame - shear wall structures for buildings.

This paper introduces the following series of papers which provide a state of the art report on the seismic desion of reinforced concrete shear wall structures. Recommendations have been derived from considerations including a first principles assessment of structural behaviour as well as a review of proposed code recommendations. Generally a descriptive presentation of recommendations has been adopted with supporting material such as observations of seismic behaviour, derivations and typical calculations being presented separately in Appendices or additional papers.

A brief outline of the content of the papers is provided as follows. The section dealing with ductile shear walls, provides a comprehensive review of previous work together with improved recommendations in areas of uncertainty. Probably the most innovative work is contained in the section dealing with walls of limited ductility. A set of design recommendations has been provided for all walls of limited ductility, irrespective of size or aspect ratio. Further papers have provided guidance in the design of other important components such as diaphragms connecting shear walls, foundation elements and secondary elements. The final paper of the series provides background information on recent earthquake damage to walls of limited ductility and points to the need for modification of some existing requirements. A list of the papers is included further on in this paper. 


\section{PERSONNEL:}

In a renewed attempt to obtain a balanced representation of interest and expertise within the group, the management committee asked the following members to join the group:

Mr I.C. Smith (Chairman)

Brickell Moss Rankine \& Hill

Consulting Engineers

Mr D. Kolston Structon Group

Consulting Engineers

Mr K.C.F. Spring

Brickell Moss Rankine \& Hill Consulting Engineers

Mr N.W. Allardice

Kingston, Reynolds, Thom \&

Allardice Ltd

Consulting Engineers

Mr L.M. Robinson

Hadley and Robinson Ltd

Consulting Engineers

Mr J.R. Binney Beca Carter Hollings \& Ferner Consulting Engineers

Prof. T. Paulay University of Canterbury

Mr O.A. Glogau Ministry of Works \& Development

Mr B.W. Buchanan Ministry of Works \& Development

Mr R.L. Williams Ministry of Works \& Development

Dr R.G. Taylor* Ministry of Works \& Development

*(Technical Secretary)

The contribution of the following members who could not attend all the meetings is also acknowledged:

Dr M.J.N. Priestley

University of Canterbury

Mr M. Wesseldine

Manukau City Council,

City Engineer's Office

The papers, as given in the following list, have been written by the authors named after obtaining a concensus of opinion during group meetings. The large amount of material presented and the limited time available did not allow study of every detail by all members. However, the overall approach presented in the papers reflects substantially, though not completely, the views of the group.

PAPERS:

\section{Section Title and Author}

A Introduction to and aims in the Design of Earthquake Resisting Shear wall Structures

I.C. Smith and R.G. Taylor
G

\section{Section}

B the Evaluation of Design Actions For Ductile Shear Walls

T. Paulay and R.L. Williams

C

D

Shear Walls of Limited Ductility

L.M. Robinson

Diaphragms

D. Kolston and B.W. Buchanan

E

Parts and Portions and Secondary Elements in Shear wall structures

N.W. Allardice

Foundations for Shear Wall Structures

J.R. Binney and T. Paulay

Low Rise Buildings of Limited Ductility

O.A. Glogau

\section{TYPES OF STRUCTURAL WALLS:}

In an attempt to classify structural walls, to be used for seismic resistance, the group took the view that the structural type factors $S$, currently specified by NZS 4203 for ductile shear walls, are applicable when the structure has the ability to deform inelastically corresponding with a displacement ductility of equal to about 4 . When this flexural ductility demand cannot be fully met, the seismic resistance of the structure should be increased so that for all shear walls, with the exception of those designed for fully elastic response, the product $\mu \mathrm{S}$ is not less than 4 .

Accordingly, the structural type factors $S$ listed in Table Al imply various degrees of ductility. It is seen that structural walls have been classified in three main groups.

(1) Ductile Shear Walls

Adequate flexural ductility is assumed to be available in walls with height to length ratios larger than two, when the design ensures that plastic hinges can form at predetermined localities. Capacity design principles, in accordance with the recommendations of Section B should be used in the design of these ductile walls. Squat shear walls are assumed to be inhibited to a certain extent in their ability to provide adequate ductility in flexural yeilding. Therefore they should be designed for larger lateral load resistance. This is achieved by the introduction of the $\mathrm{Z}$ factor in Table Al which summarises the different wall types and the corresponding values for the structural type factor. 
(2) Shear Walls of Limited Ductility

When ductile flexural hinges cannot develop in structural walls, seismically induced shear forces assume a more important role. It was assumed by the group that controlled shear cracking, while contributing little to the ductility of the structure, sill significantly increase viscous damping, and consequently will allow flexural strength to be provided corresponding with a structural type factor $S$ equal to 1.6. Section $C$ makes recommendations for shear amplifications, which are necessary to avoid brittle shear failures.

As these types of shear walls occur more commonly in low rise or small buildings, in which seismic aspects of the design may not be as critical as in tall buildings, an attempt has been made to simplify the design procedure.

For shear walls with limited ductility, the capacity design principles outlined in Section B can be applied. Alternatively, the less onerous strength design method may be used as presented on Section C. Simplicity in the

latter approach necessitated the introduction of more conservative recommendations for shear design.

(3) Walls Designed for Elastic Response

The exemptions which apply to walls designed with $S$ equal to 6 , to remain elastic during the expected earthquake, are only briefly discussed in Section $C$ as such walls in reinforced concrete are expected to be employed only rarely and because the principles of strength design which are relevant, are well established.
Notes:

i) When the height to length ratio of the wall is less than 2 some reduction in its ability for flexural ductility is assumed and accordingly

$1 \leqslant z=2.2-0.6 h_{w / \Omega_{w}} \leqslant 1.6$

but $S$ need not exceed 1.6 where $h_{w}$ is the height of thw wall and $l_{w}^{w}$ is the length of the wall.

ii) Section B recommends an interpolation between values for Type 1 and Type 3 walls when the contribution of the coupling beams is not significant.

iii) These walls are discussed in Section $C$.

iv) The likely effect of openings on the response of walls is assessed by the peripheral ratio

$$
p_{0}=\sqrt{A_{0} / A_{w}}
$$

A further chart showing wall types is presented in Table A2.

TABLE AI

RECOMMENDED STRUCTURAL TYPE FACTORS S FOR SHEAR WALLS

(To be determined separately for each direction of earthquake loading)

\begin{tabular}{|c|c|c|c|}
\hline $\begin{array}{l}\text { Type of } \\
\text { Wall }\end{array}$ & Description & $\mathrm{S}$ & \\
\hline 1 & $\begin{array}{l}\text { Two or more parallel and approximately symmetrically } \\
\text { arranged ductile canti-shear walls }\end{array}$ & 1.02 & $\begin{array}{l}\text { See Note } \\
\text { i) }\end{array}$ \\
\hline 2 & Single ductile cantilever shear walls & $1.2 \mathrm{z}$ & $\begin{array}{l}\text { See Note } \\
\text { i) }\end{array}$ \\
\hline 3 & $\begin{array}{l}\text { Ductile coupled shear walls in which a significant } \\
\text { portion of the overturning moment is resisted by } \\
\text { diagonally reinforced coupling beams }\end{array}$ & $0.8 \mathrm{z}$ & $\begin{array}{l}\text { See Notes } \\
\text { i), ii) }\end{array}$ \\
\hline 4 & Shear walls with limited ductility & 1.6 & $\begin{array}{l}\text { See Note } \\
\text { iii) }\end{array}$ \\
\hline 5 & $\begin{array}{r}\text { Limited ductile walls with openings } \\
1.6 \leqslant 0.8+4 p_{0} \leqslant 2.4\end{array}$ & . & $\begin{array}{l}\text { See Notes } \\
\text { iii), iv) }\end{array}$ \\
\hline 6 & Shear walls designed for elastic response & 6 & \\
\hline
\end{tabular}




\section{SUMMARY OF MATERIAL DISCUSSED:}

In the following paragraphs the most significant new or contentious issues are outlined or summarized to acquaint the reader with the work of the group and to give some appreciation of difficulties encountered.

The problems encountered in modelling walls to obtain useful preductions for deflections were found to be particularly important when assessing damage to secondary elements. Initially it was felt that only relative wall stiffnesses should be estimated by applying suitable factors to gross concrete properties. These are normally used when determining a distribution of forces within the structure. However, in the interests of simplicity in analysis it was decided to recommend that deflections for the purposes of satisfying code requirements could be determined by applying suitably adjusted factors to the gross concrete section properties. This allows an assessment of deflections, based on probable absolute stiffnesses, to be made directly. A more refined and favoured method of computing wall stiffness, which makes allowance for cracking and other sources of deformation is also given.

Recognition of the potential for inelastic redistribution of design actions between cantilever shear walls has resulted in the preparation of design recommendations in this area. This should allow a rationalisation in many structures.

A complete suggested procedure for the capacity design of ductile coupled shear walls has been presented and this should provide valuable guidance to designers.

A comprehensive review of the requirements for the design and detailing of wall sections has been provided. This is largely an endorsement of the material in recently published DZ 3101 Draft Code of Practice for the Design of Concrete Structures.

The designer is reminded that the elastic and potential inelastic regions in shear walls must be clearly identified so that the appropriate detailing can be provided in each region.

A thorough treatment of shear strength is presented which takes into account the following factors:

i) Locality of a shear wall section i.e. plastic or elastic regions.

ii) The level of load resistance for which shear strength is to be provided.

iii) The differences and similarities in approach to ductile walls and those of limited ductility.

The selection of shear stress levels for various cases was found to be a difficult exercise in view of the complex behaviour of concrete subjected to reversed cyclic shear action.

A suggested approach for designing walls containing holes has been presented even though there is relatively little supporting research material. It appears that the suggestions are prudently conservative if applied by competent designers.

The general notion prevails that with the use of shear walls a high level of protection of nonstructural components or secondary elements can be achieved. The need to check deformation where shear walls interact with each other or other parts of the structure is pointed out and discussed.

The section on foundations provides a classification of foundation types. The problems of providing foundations for shear wall structures or, indeed, in deciding upon a consistent design philosophy, have been considered and recommendations have been presented.

Rocking of ductile structures on their foundations is permitted at a high level of earthquake response, when it is uneconomical to provide sufficient stability to prevent rocking. However, the fundamental advantages, indicated by recent research, are also recognised and may be taken advantage of at a lower level of lateral load $(S=1.0)$ provided special studies are carried out to ensure satisfactory behaviour is obtained.

From this the designer should be able to choose a system which ensures a viable total structural system results. Generally, guidance on issues not covered in previously published papers have been provided, rather than presenting detailed design procedures.

\section{CONCLUSION:}

It is believed that considerable progress in developing the design of shear wall structures has been made as a result of the group's deliberations. In particular, much new material on the design of walls of limited ductility has been presented.

As in most areas of seismic design, advancement is progressive. For instance it may be that a review of shear stress levels is warranted after a calibration of these proposals by actual earthquakes and further test results. However, the overall philosophy and methodology for the design of shear wall structures should be found to be of value.

It is hoped that this will not only provide immediate guidance to designers and assistance to those involved with drafting codes but that the recommendations will also provide inspiration for research in the future. 
NOTATION:

Z Factor applied to structural type factor

A Aggregate area of openings in wall

$A_{W}$ Area of wall in a storey

$\mathrm{T}$ Axial tension in wall induced by coupling beams

l Distance between wall centroids

M Total overturning moment

$h_{w}$ height of wall

S Structural type factor $\ell_{w}$ length of wall

$p_{0}$ factor allowing for wall openings

$=\sqrt{\mathrm{A}_{\mathrm{O} / \mathrm{A}_{\mathrm{W}}}}$

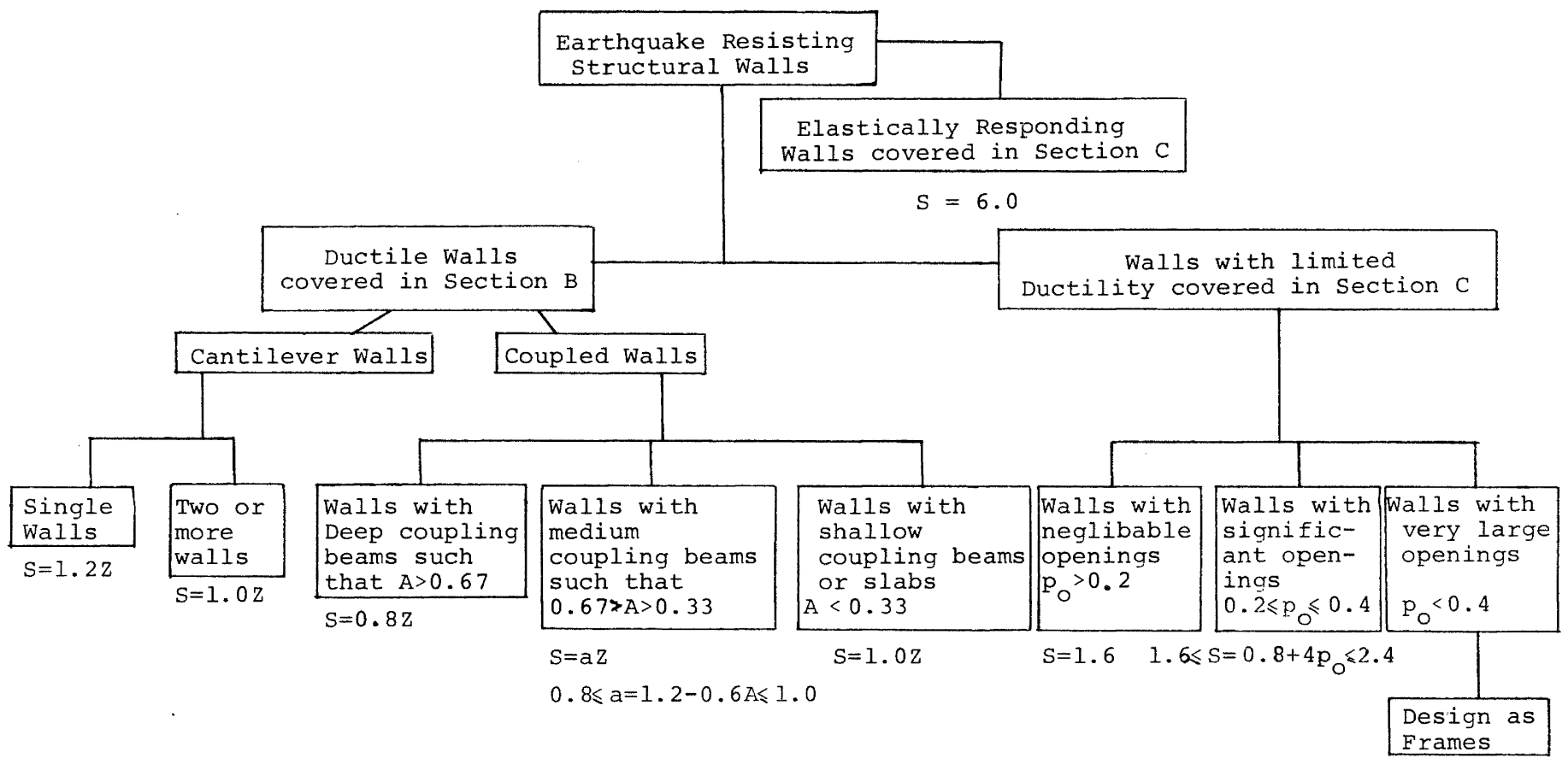

$S=2.4$

WHERE: $\quad 1.0<\mathrm{Z}=2.2-0.6 \mathrm{~h}_{\mathrm{w}} / \ell_{\mathrm{w}}<1.6$ and $\mathrm{SZ} \leqslant 1.6$

$A=\mathrm{T} \ell / \mathrm{M}_{0}$

TABLE A. 2 